determination of them has not been reached. They will doubtless be further discussed in the future.

The method employed by Turkey to denounce, upon its own initiative, extraterritorial jurisdiction, where the United States possessed it, whether by express treaty, by custom or by favored-nation clause, is contrary to the action of other countries in which extraterritorial rights have been claimed and exercised. The traditional policy of the United States has been to make its agreement to renounce extraterritoriality depend upon reforms to be accomplished in the respective countries, and when these reforms have been instituted and the results have been found or are considered satisfactory by the United States, then, and not till then has the United States renounced its extraterritoriality. See the treaty with Korea of 1882 (Art. 4), treaty with Japan of 1894 (Art. 18), treaty with China of 1903 (Art. 15), and the process of abrogation of extraterritoriality now in progress in Siam. In other cases the renunciation of extraterritoriality has not taken place until the native laws and tribunals have been superseded by those of a civilized country which has assumed a protectorate. Reference is made to the abrogation of extraterritoriality in Madagascar, Morocco, Tunis, Zanzibar, and the leased territories in China. In all these cases, however, the relinquishment of extraterritoriality has been accomplished with the consent, often expressed in a formal treaty, and as a voluntary act of the United States.

\title{
THE BRYAN PEACE TREATIES
}

In the July number of the JourNaL ${ }^{1}$ an editorial comment was devoted to Mr. Bryan's peace plan, and the treaty between the Netherlands and the United States was taken as the representative of the group, and its terms analyzed in detail. On August 13, 1914, the Senate advised and consented to the ratification of eighteen of the twenty treaties which had up to that time been submitted to it. The treaties with Panama and Santo Domingo were reserved for further consideration, as the relations between Panama and the United States are of a peculiar character, and the situation in Santo Domingo was far from satisfactory, owing to a revolution which was then in progress. The treaty with the Netherlands was very carefully considered by the Senate and a test vote was taken upon it. Upon its acceptance, the others were advised and consented to as a matter of course. Mr. Bryan's plan of communicating in advance with the Senate Committee on Foreign Relations, laying his plans before

1 Page 565. 
its members, and receiving their approval, has worked admirably and shows that co-operation between the Senate Committee and the Secretary of State is both possible and profitable, if only the Secretary of State takes the members of the Committee into his confidence.

Mr. Bryan, however, has not been content to negotiate treaties with some of the nations. He wishes, on the contrary, to secure agreements of a similar, if not an identical, kind with all the nations that believe in arbitration. On September 15th he had the very good pleasure to sign treaties of this kind with China, Spain, France, and Great Britain. After the signing of these treaties, which will undoubtedly be advised and consented to by the Senate, Mr. Bryan prepared the following statement, which the Jourval is able to print through his courtesy:

The signing of the four treaties with Great Britain, France, Spain and China bring under treaty obligations more than nine hundred millions of people. These, when added to the population of the United States and the population of the twenty-two countries with which similar treaties have heretofore been signed, brings under the influence of these treaties considerably more than two-thirds of the inhabitants of the globe. As these treaties all provide for investigation of all matters in dispute before any declaration of war or commencement of hostilities, it is believed that they will make armed conflict between the contracting nations almost, if not entirely, impossible. This government is gratified to take this long step in the direction of peace and is not only willing, but anxious to make similar treaties with all other nations, large and small. Immediately upon the signing of these treaties, telegrams were sent to the government's representatives in Germany, Russia, Austria and Belgium, communicating the fact of the signing of these treaties and expressing a desire to sign similar treaties with these countries, all of which have endorsed the principle embodied in the plan.

\section{GERMANY AND THE NEUTRALITY OF BELGIUM}

The war, it would seem, has barely begun, and yet there are charges and countercharges of the violation of international agreements and of the unwritten laws of humanity. People in an excited state of mind readily believe charges without weighing, as in a balance, the elements of proof, upon which the truth or falsehood of the charges rests, and for the sake of our common humanity it is to be hoped that the proofs will not be forthcoming. The Journal believes it unwise either to enumerate the charges or to attempt to comment upon them, reserving the right at some future time to consider them when the facts are known upon which judgment should be based. It is, however, proper to advert to one charge: namely, the violation of the neutrality of Belgium and of Luxemburg, of which Germany is accused. 